\title{
ІСТОРІя ВОАИНI
}

DOI https://doi.org/10.32782/2305-9389/2020.23.01

УДК 94:329.71[СЕЛЬ-СОЮЗ](477.8)«1922/1924»

Бортнік Тетяна,

здобувач відділу новітньої історії Інституту украӥнознавства імені Івана Крип'якевича Національної академії наук Украӥни

\section{НА ШЛЯХУ ДО СТВОРЕННЯ «СЕЛЬСОЮЗУ»: КОНСОЛІДАЦІЯ УКРАЇНСЬКОГО ПОЛІТИКУМУ ВОЛИНІ, ХОЛМЩИНИ ТА ПІДЛЯШШЯ (1922-1924)}

\begin{abstract}
Проаналізовано основні етапи діяльності украӥнських діячів Холмщъини та Підлящшя, Волині. Висвітлено сочіально-економічні обставини та політичний контекст, які впливали на життя украӥнської громади окреслених регіонів, отже, і на їхню політичну активність. Показано основні етапи самоорганізації української інтелігенції, яка в перші роки після Першої світової війни намагалась вирішити нагальні потреби місцевого українства: творення господарських та культурно-освітніх осередків, поступовий перехід до політичної діяльності.

Показано, щзо одним із перших таких кроків у політичній сфері стало підписання украӥнським активом так званого «Меморіалу православного населення Холмщини». У документі, надісланому украйнською делегацією до Варшави, містилось прохання про творення Украӥнського комітету, який б репрезентував перед владою питання освітньо-культурного та релігійного характеру, Украӥнського доброчинного товариства.

Стверджено, що ігнорування українських вимог адміністрацією було продиктоване трактуванням українського питання як суто внутрішньої проблеми (відсутність організованого українського життя в політичній, суспільно-економічній та культурній сферах) та остаточним переходом до асиміляційного курсу політики.

Зауважено, щз вибори до польського сейму та парламенту в листопаді 1922 р. стали переломним моментом для українських діячів окресленого терену. Активізувавщи свої зусилля інтелігенція створила Холмський та Волинський виборчі комітети, які згодом злились в одну структуру - Український иентральний виборчий комітет (УЦВК). Украӥнський центральний виборчий комітет як самостійна організачія разом із представничтвами інших начіональних меншин сформували єдину виборчу платформу - Блок начіональних меншин (БНМ).

Підсумовано, щз вибори 1922 р. були успішними для політикуму Волині, Холмщчини та Підляшшя та стали першим досвідом парламентської діяльності в новопосталій Польській державі.
\end{abstract}

Ключові слова: Холмщчина, Підляшия, Волинь, «Меморіал православного населення Холмщини», вибори 1922 р., Блок національних меншин.

Bortnik Tetiana. On the way to create a "SelSojuz": consolidation of the Ukrainian politics of the Volhynia region, Kholm and Podlasie regions (1922-1924)

The main phase of activity of Ukrainian leaders of Kholm and Podlasie, Volhynia regions are analyzed. The socioeconomic circumstances and political context that influenced the life of the Ukrainian community in the outlined regions, and thus their political activity, are highlighted. The basic steps of self-organization of the Ukrainian intelligentsia. There are tried to solve the needful needs of local Ukrainians in the first years after the First World War: the creation of economic and cultural-educational centers, the gradual transition to political activity.

It is shown, that one of the first such steps in the political sphere was the signing of the so-called "Memorial of the Orthodox population of Kholm regon" by Ukrainian activists. The Ukrainian delegation sent to Warsaw a request for establishment of the Ukrainian committee, that represented to the authorities issue of the educational, cultural and religious sphere of the Ukrainians, and possibility of foundation The Ukrainian charitable society.

It is noted that elections to the Polish Sejm and Parliament in November 1922 was a turning point for Ukrainian leaders in this area. Intensifying their efforts, the intelligentsia created the Kholm and Volhynia election committees, which later merged into one structure - the Ukrainian Central Election Committee (UCEC). The Ukrainian Central Election Committee, as an independent organization, together with the representations of other national minorities, formed a single election platform, the Bloc of National Minorities (BNM).

The elections of 1922 were successful for the politicians of Volhynia, Kholm and Podlasie and became the first experience of parliamentary activity in the newly formed Polish state are concluded.

Key words: Volhynia, Kholm and Podlasie, «Memorial of the Orthodox population of Kholm regon», elections of 1922, Bloc of National Minorities. 
Вступ. Холмщина та Підляшшя - частини української етнографічної території, що знаходились у складі Люблінського воєводства Республіки Польща. Наприкінці 1918 р. - на початку 1919 рр. ці терени знову відходять до відновленої Польської держави. Перехід цих територій остаточно узаконив Ризький мирний договір, укладений 18 березня 1921 р. [3, с. 29]. Після включення західноукраїнських земель до Польщі проблематика міжнаціональних відносин стала однією із найголовніших у державній політиці. Однак, незважаючи на задекларовані в Конституції 1921 р. (та узгоджені міжнародними договорами) права національних меншин на практиці уряд та адміністрація керувалися принцами, які перешкоджали розвитку та дискримінували національні меншості [22, с. 125].

Поразка федералістських задумів Ю. Пілсудського та підписання Ризького миру ознаменували перехід до програми національної демократії. Тому, як зауважував польський дослідник А. Айненкель, ключовим гаслом у політиці стає ідея «щоб креси і наші міста не тільки за належністю, але і за національним духом культури були польськими». По суті, на практиці це означало, що українське питання загалом трактувалось лише як внутрішньопольська проблема, а національна політика, яка проводилась, мала сприяти інтеграції східних територій із державою [1, с. 145-149].

Українське населення Холмщини та Підляшшя опинилось у складних умовах життя у 1920-х рр. не лише з погляду політичної, а й соціально-економічної ситуації. Після так званої евакуації Першої світової війни [13, с. 29-30] значна частина української людності перебувала за межами краю, станом на 1921 р. після завершення репатріаційного процесу чисельність українців не перевищувала довоєнного рівня [20, с. 37].

У таких складних умовах назрівала потреба політичної консолідації українських діячів Холмщини та Підляшшя, Волині (яка перебувала у схожому становищі). Безпосередньою спонукою до активної самоорганізації стали парламентські вибори 1922 р., які бойкотували більшість політикуму Галичини $[10$, c. 42$]$. Також в умовах післявоєнної розрухи потребувало вирішення аграрне питання, яке загострювала політика військового осадництва на теренах східних польських воєводств [9, с. 116-117]. Отже, особливо актуальною була політична діяльність української інтелігенції краю, покликана вирішити проблеми національно-культурного і соціального спрямування (зокрема селянства). Однією 3 таких структур, покликаною вирішити окреслені проблеми, став «Сельсоюз» (Українське соціалістичне об'єднання «Селянський союз»). Партія лівого спрямування виникла у 1924 р. за ініціативи українських політичних діячів Холмщини, Підляшшя та Волині [19, с. 265].

Аналіз останніх досліджень та виділення не вирішених раніше частин загальної проблеми. Публікації радянського часу висвітлюють проблематику діяльності партій міжвоєнного періоду, які належали до лівого блоку та з позицій соціалізму, комунізму боролися за покращення життя селянства та робітництва. Це, зокрема, роботи М. Герасименка та Б. Дудикевича [4], I. Заболотного [7], І. Васюти [2], можна виокремити публікації Г. Сизоненко [21], С. Макарчука [16], польських авторів (періоду соцтабору) С. Кжикали [24], Р. Шафаліка [30], В. Менджецького [27].

Чимало розвідок, виданих після 1990 р., присвячені виборам 1922 та 1928 рр. до Польського сейму та сенату, консолідації українства, зокрема і Волині, Холмщини та Підляшшя (які не бойкотували вибори 1922 р, на відміну від галичан), їхньої подальшої діяльності [8]. Окремі, здебільшого оглядові сюжети національно-політичної діяльності української громади Холмщини та Підляшшя міжвоєнного часу є в працях Є. Пастернака [17], М. Горного [5; 6], Ю. Макара [12-16]. Натомість більш вагомими є роботи Я. Цецика та М. Кучерепи [10; 11], Ю. Перги [18-20], Г. Купріяновича [25], М. Шуміла [31-33]. Незважаючи на кількість публікацій, немає цілісної роботи, яка би відображала не лише досвід парламентської праці, а й попередню роботу української інтелігенції щодо боротьби за національно-політичні права громади.

Мета статті - комплексно проаналізувати діяльність українських сил у перші повоєнні роки в Холмщині та Підляшші, Волині, їх самоорганізацію, перехід до політичної діяльності у складі Українського виборчого комітету та Блоку національних меншин.

Виклад основного матеріалу. Після завершення Першої світової війни для українства Холмщини та Підляшшя однією з головних проблем, які потребували вирішення, було повернення на рідні терени після так званого біженства 1915 р. Репатріація розпочалася наприкінці 1918 р., коли невеликі групи населення зуміли повернутись на спустошені терени [17, с. 182]. Часто збережені будівлі були реквізовані або ж зайняті осадниками, також виникали труднощі з подальшим працевлаштуванням, адже місцева польська влада не надто сприяла вирішенню цієї проблеми [20, с. 40]. Натомість активні українські діячі, які мали досвід організаційної роботи в попередні роки національно-визвольних змагань, намагались допомогти своїй громаді. Серед них чільне місце займає діяльність Антона Васиньчука (Васильчука): у 1917 р. він був делегатом уряду УНР від Холмщини, у 1918 р. призначений УНР міністром 
у «справі репатріації репатріації «біженців» із Холмщини та Підляшшя» з осідком у Рівному [31, с. 57]. Згодом спільно з представниками Німеччини та Австро-Угорщини, Міжнародним Червоним Хрестом А. Васиньчук зорганізував міжнародну комісію з репатріації в Ковелі, де його рідний брат Павло очолював український відділ [31, с. 57-58].

Наступні кроки українського активу полягали в захисті своїх прав шляхом створення господарських, культурно-освітніх організації, а згодом й політичних структур [6, с. 176]. Аби продемонструвати лояльність до нової польської влади та актуалізувати проблеми української спільноти Холмщини та Підляшшя 30 вересня 1919 р., у м. Холмі за ініціативи Антона Васильчука, Петра Грицая та Хоми Кульгавого [14, с. 233-234] складений «Меморіал православного населення Холмщини» («Меморіал у справі української людності на Холмщині») [28, с. 2]. На початку відозви автори наголошують, що їх засади полягають «у прийнятті польської державності», проте з моменту відновлення Польщі розпочалась «виразна антиукраїнська політика, арешт української інтелігенції, заборонено вчителям навчати дітей рідної мови, а також подавати звернення до адміністративних установ українською мовою, $<\ldots>$ закриті православні церкви, депортовані православні священики» [28, с. 2]. Ситуацію також погіршує те, що досі відбувається процес повернення українців із теренів «широкої Росії», їхня подорож часто триває рік, а після повернення на них очікує боротьба за землю, а у випадку інтелігенції - поліційний нагляд та арешти «як відповідь за переслідування більшовиками поляків в Росії, < ..> хоча ми з культурної точки належимо до Заходу і за царського урядування нас переслідували як і поляків» [28, с. 2].

Тому «для вирішення пекучих справ українського населення просимо про негайне надання нам дозволу для організації Українського комітету з осідком у Холмі, доброчинних українських організації, відкриття українських народних шкіл там, де $є$ у цьому потреба, відкриття українських гімназій, та дозволу на використання української мови в установах і судах, забезпечення відповідної кількості православних церков, де цього вимагає ситуація, врахування при втілення аграрної реформи прав українських селян на землю» $[29$, с. 2]. До майбутнього Українського комітету мали входити представники різних верств українства, які б репрезентували та інформували місцеву та центральну владу про стан українських справ. Також передбачалося напрацювання статуту, який буде поданий на затвердження Міністерства внутрішніх справ, створення Українського доброчинного товариства [29, с. 2].

Із цим документом та проханням про створення Українського комітету на початку жовтня 1919 р. вирушила українська («православна») делегація до Варшави (Міністерства внутрішніх справ). Передбачалося, що Український комітет опікувався б українськими справами, зокрема в освітній та релігійній сфері. Отримавши відмову у створенні цієї організації, українські представники виступили з проханням про заснування Українського доброчинного товариства та приватної української гімназії, але адміністрація знову не погодила такі клопотання [23, с. 2].

Однією з підстав такого рішення, на думку авторського колективу монографії «Від депортації до депортації», був висновок Міністерства внутрішніх справ Польщі від 2 грудня 1919 р., в якому зауважено, що в української громади відсутні «свідомі політичні і суспільні прояви, адже немає політичних, визнаннєвих і економічних організацій». Натомість українців звинувачували в «певних більшовицьких тенденціях» [14, с. 234]. Також подано характеристику української інтелігенції, іiі поділено на три групи. До найбільш чисельної зараховували індиферентних щодо своєї національної, чи соціальнорелігійної приналежності, до другої групи - урядовців та православних священиків, які ностальгували за російським пануванням, остання і найменш чисельна група - це українська молодь, яка гуртувалась навколо А. Васиньчука [26, с. 143].

Новим поштовхом для подальшого розвитку українського руху став Варшавський договір, підписаний С. Петлюрою та Ю. Пілсудським 21 квітня 1920 р. Українські діячі покладали надії на створення національної територіальної автономії для українців Польщі. Українська делегація з Холмщини, Підляшшя, Полісся та Волині разом із представниками інших національних меншин та польських політичних партій узяла участь у конференції, що проходила у Варшаві 9-10 червня 1920 р. [9, с. 120; 14, с. 236]. Українська сторона подала до розгляду меморандум, в якому сформулювали низку вимог щодо утворення окремої адміністративної одиниці на теренах Холмщини та Підляшшя, Західної Волині, яка б користувалась автономними правами: використання польської та української мови в місцевій адміністрації, заснування українського самостійного шкільництва, надання самоврядності Православній церкві, податкових пільг для населення, яке втратило майно під час війни, та сприяння поверненню біженців із Російської держави. У результаті переговорів була утворена спеціальна урядова комісія, яка мала лобіювати ці питання, проте жодних конкретних результатів її діяльність не принесла [9, с. 120; 14, с. 236]. Натомість згідно із законом від 5 грудня 1920 р. був відновлений устрій, що існував до створення Холмської губернії на теренах Холмщини та Підляшшя. Згодом, у 1922 р. прийнято нове 
розпорядження, яке передбачало перехід до адміністративного поділу, який би враховував етнічні особливості регіонів, а з 1924 р. й місцеве самоврядування (хоча, по суті, ці постанови мали декларативний характер, аби спонукати Раду Антанти визнати приєднання Західної України до Польської держави) [14, с. 237].

1922 р. у зв'язку із проведенням виборів до сейму та сенату Польщі ознаменував новий етап у діяльності української інтелігенції Волині та Полісся, Холмщини та Підляшшя. 18 квітня 1922 р. у Холмі відбувся з'їзд діячів Холмщини та Підляшшя (загалом 165 діячів, 41 гість, серед яких були представники Волині, польських та українських партій), які постановили брати участь у майбутніх виборах до парламенту, оголошено про створення виборчого комітету. Головою зібрання обрано А. Васиньчука, його заступником - Й. Скрипкку, секретарем - Я. Войтюка $[14$, с. $237 ; 22$, с. 126]. Опісля аналогічний комітет постав і в Луцьку, головним завданням якого було координація зусиль українства Волині та Полісся. Холмський та волинські виборчі комітети об'єдналися в один, на чолі з С. Маківкою, його заступником призначено А. Васиньчука та Й. Скрипку. У кількісному вимірі до організації увійшли 12 діячів із Холмщини та Підляшшя, 4 - із Волині та Полісся [9, с. 122].

Український центральний виборчий комітет (УЦВК) налагодив зв'язок з іншими національними меншинами, був організований протягом липня-серпня 1922 р. Українсько-білоруський блок, також до них приєдналися росіяни, німці та євреї. У серпні 1922 р. Український центральний виборчий комітет на правах самоврядної одиниці увійшов до складу Блоку національних меншин (виборче об'єднання створене в серпні 1922 р. у Варшаві, яке репрезентувало вищезгадані національні меншини, за винятком чехів, які не приєднались до них) [9, с. 122; 10, с. 42-43; 22, с. 126].

Виборча програма УЦВК, опублікована у вересні 1922 р., містила низку вимог, зокрема «забезпечення етнічним меншинам рівних із поляками прав, залучення українців до державної служби, гарантію рівності української мови» [10, с. 43]. Під час передвиборчої компанії УЦВК проводив збори, віча, де поширювали прокламації-заклики із проханням не голосувати за польські партії, адже лише українські діячі зможуть справді відстояти їхні права, намагався провадити агітацію серед німців та чехів Волині, хоча їх лідери не підтримували український блок [10, с. 43-44].

Польська адміністрація намагалась перешкодити активній діяльності українського політикуму окреслених регіонів, послабити його єдність, проводила заходи на підтримку «Державного об'єднання на кресах» (проурядового утворення), навіть вдавалась до арештів активістів УЦВК, залякувала селян, які мали намір взяти участь у передвиборчих зборах [22, с. 127]. Ще одним елементом протидії діяльності УЦВК та загалом українського руху була підтримка адміністрацією інших українських сил (проурядових): Союзу народних рад, Українського народного Єднання та Української народної партії [22, c. 130-132].

За підсумками виборів до сейму та сенату 1922 р. від Блоку національних меншин із теренів Холмщини та Підляшшя, Волині та Полісся отримано 57,3\% та 61,8\% голосів відповідно. Загалом від БНМ 20 депутатів українців увійшло до сейму та 6 - до сенату [9, с. 122]. Задля подальшої консолідації сил 22 листопада 1922 р. у Ковелі українські посли та сенатори зорганізували Українську парламентську репрезентацію (УПР), иї головою обрали Антона Васиньчука [31, с. 59]. УПР під керівництвом А. Васиньчука була готова до співпраці з польським урядом. Відбулася зустріч А. Васиньчука із прем'єр-міністром Польщі Владиславом Сікорським, де обговорювалось питання українського шкільництва, православної церкви та допуску українців до державної служби. Цілком ймовірно, що прем’єр дав певні обіцянки щодо поступок українцям у культурно-освітній та соціально-економічній сфері, проте, на думку польського дослідника українського походження М. Шуміла, досі не зрозуміло, чи справді існувала так звана «угода між українським клубом та урядом Сікорського». Хоча завдяки певним домовленостям українські посли голосували за підтримку уряду В. Сікорського [31, с. 59-60].

Задекларовані в тій чи іншій формі поступки українцям не були реалізовані, навпаки, надалі існував ряд заборон щодо культурно-освітнього та церковного життя української громади. У відповідь на пасивну позицію влади УПР поступово переходить на більш радикальні позиції, А. Васиньчук дедалі більше піддається критиці за своє «угодовство» владі [31, с. 60]. Напередодні засідання Найвищої Ради Антанти у 1923 р., яка мала розглядати питання включення західноукраїнських земель до Польщі, за умови надання останньою широкої автономії українцям, в середовищі УПР дедалі виразніше звучала пропозиція солідаризації з українством Східної Галичини. Натомість голова УПР А. Васиньчук виступив проти таких кроків, подав у відставку, а новим очільником було обрано С. Підгірського, а П. Васиньчук залишився на пості заступника парламентської репрезентації [31, с. 60].

Переломними для Української парламентської репрезентації стала зміна очільника, голосування проти нового державного бюджету у травні 1923 р. [9, с. 123], після яких відбувся остаточний перехід 
в опозицію до польської адміністрації. Також варто зауважити, що УПР втрачає свою монолітну структуру: група осіб, серед яких і П. Васиньчук, засновує в межах фракції соціалістичне угруповання, члени якого згодом засновують Українську соціал-демократичну партію (УСДП) (не в останню чергу завдяки впливу Комуністичної партії Західної України) [9, с. 123; 32, с. 60-61]; інші парламентарі, які тяжіли до правих поглядів, зблизились із галицькою Українською Народною Трудовою Партією (відкрито на травневому з'їзді 1923 р. виступили проти рішення Найвищої Ради Амбасадорів щодо приєднання Галичини до Польщі) [32, с. 76]. Аби протистояти цим розколам, А. Васиньчук у травні 1923 р. після 2-місячної перерви повертається до діяльності в УПР. Васиньчук разом із 5 депутатами оголошує про створення групи автономістів-федералістів, які відстоювали «здобуття для українських етнографічних територій у кордонах Польщі широкої національно-територіальної автономії». Однак, не маючи підтримки в УПР та шансів реалізувати власну програму, в жовтні 1924 р. А. Васиньчук виходить зі складу УПР [32, с. $76-77 ; 31$, с. 60$]$.

Новий етап у діяльності політичних діячів Холмщини та Піляшшя, Волині ознаменувала поява «Сельсоюзу» (Українського соціалістичного об'єднання «Селянський союз»), який постав у серпні 1924 р. завдяки послам-соціалістам у м. Холмі, після арештів українських діячів та закриття владою УСДП [19, с. 265; 32, с. 93].

Висновки й перспективи подальших досліджень. Українські діячі Холмщини та Підляшшя, Волині завдяки консолідації власних сил у перші повоєнні роки зуміли отримати досвід парламентської діяльності. Найбільший вплив та підтримку серед місцевого населення, як продемонстрували результати виборів 1922 р., отримав Блок національних меншин, складником якого був й Український центральний виборчий комітет. Українська парламентська репрезентація актуалізувала «українське питання», хоча як єдина фракція проіснувала недовго.

\section{Література:}

1. Айненкель А. Українське питання в політиці в II Речі Посполитої та в концепціях і заходах українських політичних сил у міжвоєнний період (1918-1939). Україна-Польща: важкі питання : матеріали XI міжнародного семінару істориків «Українсько-польські відносини під час Другої світової війни». Варшава, 26-28 квітня 2005 року. Варшава, 2006. T. 10. C. $141-154$.

2. Васюта I. Формування робітничо-селянського союзу в революційній боротьбі на Західній Україні 1921-1939. Львів : Видавництво при Львівському державному університеті видавничого об’єднання “Вища школа”, 1988. 172 с.

3. Винниченко I. Українці Берестейщини, Підляшшя, Холмщини в першій половині XX століття. Хроніка подій. Київ, 1997. $288 \mathrm{c}$.

4. Герасименко М., Дудикевич Б. Боротьба трудящих Західної України за возз'єднання з Радянською Україною (1921-1939 рр.). Київ, 1955. 224 с.

5. Горний М. Українська інтелігенція Холмщини і Підляшшя у ХХ ст. Львів, 2002. 324 с.

6. Горний М. Прометеї Холмської землі: люди, які присвятили себе збереженню українства на Холмщині. Львів : СПОЛОМ, 2010. $230 \mathrm{c}$.

7. Заболотний І. Нескорена Волинь: Нариси історії революційного руху на Волині. 1917-1939. Львів, 1964. 213 с.

8. Зайцев О. Представники українських політичних партій Західної України в парламенті Польщі (1922-1939рр.). Український історичний журнал / За ред. М. Коваля. Київ : Інститут історії України, 1993. Вип. 1. С. $72-84$.

9. Крамар Ю. Парламентські вибори 1922 року в Польщі та участь у них політичних сил Західної України. Украӥнці Холмшини і Підляшщя: історична доля, духовна і матеріальна культура впродовж віків : збірник наук. праць / упор. М. Кучерепа. Луцьк : ВАТ «Волинська обласна друкарня», 2010. Т. 2. С. 115-124.

10. Кучерепа М., Цецик Я. Українські національні партії на Волині (1921-1939 роки): у 2 частинах. Луцьк : Волинський національний університет ім. Лесі Українки, 2011. Ч. 1. 304 с.

11. Кучерепа М., Цецик Я. Українські національні партії на Волині (1921-1939 роки): у 2 частинах. Луцьк : Волинський національний університет ім. Лесі Українки, 2011. Ч. 2 Документи і матеріали. 292 с.

12. Макар Ю. Українська холмсько-підляська проблема у внутрішній політиці Другої Речі Посполитої. Украӥна Європа-Свim. 2009. Вип. 3. С. 32-46;

13. Макар Ю. Холмщина - терен українсько-польського етнічного пограниччя. Українці Холмщини і Підлящши: історична доля, духовна і матеріальна культура впродовж віків : збірник наук. праць / упор. М. Кучерепа. Луцьк : ВАТ «Волинська обласна друкарня», 2010. Т. 2. С. 23-32.

14. Макар Ю., Горний М., Макар В., Салюк А. Від депортації до депортації. Суспільно-політичне життя українців холмсько-підляських українців (1915-1947). Дослідження. Спогади. Документи. Чернівці : Букрек, 2011. Т. 1. Дослідження. $880 \mathrm{c}$.

15. Макар Ю.І. Холмщина і Підляшшя в першій половині XX століття. Історико-політична проблематика. Львів : Інститут українознавства НАН України ім. І. Крип'якевича, 2003. 88 с.

16. Макарчук С. Этносоциальное развитие и национальные отношения на западноукраинских землях в период империализма. Львов : Высш. шк. Изд-во при Львов. ун-те, 1983. 255 с.

17. Пастернак Є. Нарис історії Холмщини і Підляшшя. Вінніпег, Торонто, 1989. 465 с. 
18. Перга Ю. Діяльність українського товариства доброчинної «Рідна хата» 1919-1930 рр.. Часопис української історії. 2014. Вип. 30. С. 95-100.

19. Перга Ю. Створення Українського соціалістичного об'єднання «Селянський союз» та роль політичних діячів Холмщини у цьому процесі. Дні науки історичного факультету : Матеріали VIII Міжнародної наукової конференції студентів, аспірантів та молодих вчених. Київ, 2015. С. 265-267.

20. Перга Ю. Суспільно-політичне життя українців Холмщини та Підляшшя 1918-1939 рр. : дис. ... канд. іст. наук : 07.00.01. Київ : Інститут історії України НАН України, 2016. 190 с.

21. Сизоненко Г. Сель-роб у боротьбі за возз'єднання. Львів : Каменяр, 1971. 174 с.

22. Цецик Я. Участь українського населення Волині та Холмщини у Парламентських виборах 1922 року. Україниі Холмщини і Підляшшя: історична доля, духовна і матеріальна культура впродовж віків : збірник наук. праць / упор. М. Кучерепа. Луцьк : ВАТ «Волинська обласна друкарня», 2010. Т. 2. С. 125-132.

23. Hołówko T. Sprawa mniejszości a Chełmszczyzna. Robotnik. Centralny organ P.P.S. 1919. 28 grudnia. № 408 (785). S. 2.

24. Krzykała S. Z dziejów K P P na Lubelszczyźnie (1918-1923). Lublin 1961, 297 s.

25. Kuprianowicz G. Ukraińskie życie kulturalno-oświatowe i ekonomiczne na Chełmszyźnie i południowym Podlasiu w latach 1918-1926. Rocznik Chetmski. 1995. T. 1. S. 171-210.

26. Litwiński R. Obraz życia społeczno-politycznego międzywojennego powiatu chełmskiego w doniesieniach władz administraji ogólnej. Rocznik Chetmski. 2007. T. 11. S. 129-157.

27. Mędrzecki W. Województwo wołyńskie 1921-1939. Elementy przemian cywilizacyjnych, społecznych i politycznych. Wroław: PAN Instytut Historii, Wydawnictwo Ossolineum, 1988. $202 \mathrm{s.}$

28. Memorial prawosławnej ludności chełmskiej. Ziemia Lubelska (Lublin). 1919. 7 pażdzernika. № 411. S. 2.

29. Memorial prawosławnej ludności chełmskiej. II. Ziemia Lubelska (Lublin). 1919. 8 pażdzernika. № 412. S. 2.

30. Ruch ludowy na Lubelszczyźnie. Materiały z sesji naukowej zorganizowanej przez WK ZSL w Lublinie / Red. J.R. Szaflik. Lublin : Wydawnictwo Lubelskie, 1964. 409 s.

31. Szumiło M. Anton i Pawło Wasyńczykowie - ukraińscy działacze narodowi z Chełma. Українці Холмщини і Підляшия: історична доля, духовна і матеріальна культура впродовж віків : збірник наук. праць / упор. М. Кучерепа. Луцьк : ВАТ «Волинська обласна друкарня», 2010. Т. 2. С. 56-64.

32. Szumiło M. Antoni Wasyńczuk 1885-1935. Ukraiński działacz narodowy i polityk. Lublin : Wydawnictwo UMCS, 2006. 147 s.

33. Szumiło M. Działalność Antoniego Wasyńczuka w ukraińskim ruchu narodowym na Ziemi Chełmskiej i Podlasiu w latach 1919-1922. Rocznik Chetmski. 1999. T. 5. S. 171-190. 